\title{
EVALUATION OF TWO DISINFECTION PROGRAMS IN DISINFECTING POULTRY HOUSES UNDER FIELD CONDITIONS
}

\author{
JIHAN M. BADR and AMAL I. YOSEIF \\ Poultry Dis. Dept., Animal Health Research Institute, Dokki, Giza, Egypt. \\ Email: Jihanbdr@yahoo.com
}

\section{ABSTRACT}

Received at: $27 / 11 / 2013$

An evaluation of the efficacy of the use of either formaldehyde (10\% formalin) or peroxygen commercial products in disinfection of battery cage poultry houses was estimated under field conditions. For this purpose, swab samples were collected from three different sites and from drinking water dispensers from four battery caged broiler and layer houses before and after cleaning and disinfection. Also,

Accepted: 26/11/2014 water samples were collected from the original well water source and the storage water tanks (main and houses storage water tanks) before cleaning and disinfection. Total colony counting was used in the evaluation of both swabs and water samples followed by bacteriological examination for identifying the contaminant bacteria. The results of the examination of water samples revealed that in spite of sterility of original water source there was sever contamination of the stored water in the storage tanks with different types of pathogenic contaminant bacteria including Staphylococcus aureus, E.coli, coliforms, Pseudomonas earuginosa and Proteus spp.. The same contaminant bacteria were isolated from the swab samples in addition to salmonella typhymiurium contamination which was isolated from batteries and floors of both broiler and layer houses. On the other hand, both the tested disinfectant products were significantly effective $(p<0.001)$ in decline the viable total colony count from different sites of each house and from drinking water dispensers from either broiler or layer cage houses with depletion percentage reached $99.999 \%$ but the use of formaldehyde product failed to overcome the pathogenic contaminant bacteria except for salmonella typhymiurium contamination. The efficiency of the disinfection was more effective in broiler houses than in the layer ones. On conclusion, a high standard planning of cleaning is of great importance before the application of the disinfection process and the correct usage of disinfectants in addition to, an effective program of eradication of rodents and insects should be applied is important for a successful disinfection and biosecurity program. Also, the obtained data highlights the emergence of the necessity of improving farmers' and hygiene specialists' education on the use of disinfecting products in poultry houses. It was recommended to use more environmental friendly safe and efficient disinfectants as peroxygens to be alternative to the use of formaldehyde in disinfection of poultry houses which may soon become illegal in some countries due to its health hazard and environmental concerns.

Keywords: Efficacy, Formaline, Disinfection program

\section{INTRODUCTION}

Current proposals for a new Animal health strategies and new industry guides for good hygiene practices in broiler and layer production (Anonymous, 2008; Anonymous, 2010) should have special biosecurity program including effective cleaning and disinfection. The effectiveness of onfarm biosecurity use of reliable disinfectants for housing, drinkers and feeders which is of fundamental importance to these control measures, particularly in all-in-all-out systems.

A biosafety program consists of actions and measures aiming at improving poultry hygiene and health during the production process (COBB, 2003). This program becomes stricter as it goes up the pyramid of broiler production, from commercial farms to pure breed farms (Lauandos et al., 2005).

Disinfectants are important components of a biosecurity program. The objective of disinfection is to reduce microbial populations (Eckman, 1994). One of the most effective methods to reduce the level of pathogens includes the application of proper management and husbandry practices, such as all-in all-out system (Wierup, 2000) and regular cleaning and disinfection, especially before introducing a new flock to the farm (Doerning, 1998). The choice of disinfectants is critical in establishing a successful 
sanitation programs not all the disinfectants are effective against the major pathogens that cause economic diseases in poultry (Rodgers et al., 2001). Glutaraldehyde and formaldehyde are known to alkylate and create cross-links within protein molecules and to bind to cell wall peptidoglycans. Formaldehyde also forms DNA protein cross-links. It acts principally via damage to the cell envelope. Aldehydes, especially formaldehyde, are not readily inhibited by organic material (Gorman et al., 1980). Peroxygens are another group of oxidizing agents, generally using peracetic acid to disrupt lipid membranes, proteins and nucleic acids via attack by reactive species such as the hydroxyl radical $\mathrm{OH}$. Peracetic acid is active in the presence of organic debris (McDonnell and Russell, 1999), although such material reduces the effect of all the oxidizing disinfectants owing to consumption of the active chemical species by reaction with organic matrices (Chapman, 2003; Russell, 2004). Different disinfectants will be affected to different extents by characteristics of the diluting water, the organic debris, the physiological state (including nutrient and moisture stress) of the pathogens and the nature of the surfaces involved (Brown et al., 1991; Davison et al., 1996; Bessems, 1998; Ward et al., 2005).

The aim of the current investigation was to study the efficacy of two disinfection programs after common cleaning in both battery cage broiler and layer houses and to study the effectiveness of two different used commercial disinfectants in the efficiency of the biosafety program under field conditions. Also to study the possibility of use of environmental friendly disinfectants as alternative to health threaten one.

\section{MATERIALS and METHODS}

\section{Disinfection Products:}

Three commercial disinfectants products were used and were diluted according to the manufacturers' recommended working concentrations:

1- Disinfectant (1): a 10\% (vol/vol) commercial formalin dilution of the standard $37 \%$ commercial dilution, was applied by fogging using a highpressure washer to run-off point

2- Disinfectant (2): Peroxygen products consist of 2 commercial products:

A- Degaclean 51(peroxyacetic acid 5\%, hydrogen peroxide $26 \%$ and acetic acid $6 \%-7 \%$ evonik products-Germany) used in removing of organic matter and biofilm before disinfection of poultry houses. Applied by spraying into the apex of the roof and work down the walls to the floors under pressure of $5-10 \mathrm{ml} / 1$ according to the intensity of organic matter up down and left for 30 minutes then drained with water.

B- Peraclean 15 (consisted of peracetic acid 15\%, hydrogen peroxide $22 \%$ and acetic acid $15 \%-18 \%$ evonik products-Germany) applied in concentration of $5-10 \mathrm{ml} / 1$ by spraying into the apex of the roof.

\section{Method of disinfection:}

Method (1): application of $10 \%$ (vol $/ \mathrm{vol})$ commercial formalin dilution of the standard 37\% dilution.

Method (2): Disinfection using Degaclean 51 (step 1) followed by Peraclean 15 (step 2) according to the manufacturers' recommended working concentrations.

Table 1: The used chemical disinfectants and the used dilutions.

\begin{tabular}{lccc}
\hline Disinfectant & Dilution & Supplier & Active ingredients \\
\hline Formalin & $\begin{array}{c}10 \% \text { (vol/vol) formalin } \\
\text { dilution of the standard 37\% } \\
\text { commercial dilution }\end{array}$ & & Formaldehyde \\
\hline Degaclean 51 & $\begin{array}{c}5-10 \mathrm{ml} / \mathrm{l} \text { applied by foam } \\
\text { spraying }\end{array}$ & $\begin{array}{c}\text { evonik products- } \\
\text { Germany }\end{array}$ & $\begin{array}{c}\text { peroxyacetic acid 5\%, hydrogen } \\
\text { peroxide } 26 \% \text { and acetic acid } 6 \%-7 \%\end{array}$ \\
\hline Peraclean 15 & $3 \mathrm{ml} / 1$ & $\begin{array}{c}\text { Evonik products- } \\
\text { Germany }\end{array}$ & $\begin{array}{c}\text { consisted of peracetic acid } 15 \%, \\
\text { hydrogen peroxide } 22 \% \text { and acetic acid } \\
15 \%-18 \%\end{array}$ \\
\hline
\end{tabular}

\section{Disinfectant Evaluation:}

For evaluation of the two commercial disinfectants, swab samples were taken from different sites of both cage broiler (4 houses) and layer chicken houses after getting rid of the last flocks of broiler and laying hens that were suffered from sanitary problem. (4 houses) before cleaning and disinfection. Prior to disinfection, all houses were washed by soap and water, and scraping the organic materials by different scraping tools manually then rinsed by water using a pressure washer and allowed to dry. Half the numbers of each house type (either broiler or layer) were disinfected using method (1), while the remaining houses were disinfected using method (2). In all cases the 
disinfectants were applied to all surfaces of the houses. Houses were restocked 1 day after the disinfectants had dried out from the house surfaces.

Sample collection: A total of 240 swab samples were collected from the walls, batteries and floors of battery cage broiler and layer houses (ten swabs for each place in each house) on sterile saline solution before and after cleaning and disinfection of the tested houses. Also, water samples were collected from the original drinking water (well) source (1 sample), the main storage drinking water tank (1 sample) and the poultry houses storage drinking water tanks (8 samples) in addition to 80 swab samples were collected from water dispensers of the examined houses (10 swabs per house) before cleaning and after cleaning and disinfection of the tested houses. The collected samples were placed in a cooler box with ice packs $\left(4-10{ }^{\circ} \mathrm{C}\right.$ ) and transported immediately within few hours (not exceed 24 hours) to the bacteriology lab of Poultry Diseases Department Animal Health Research Institute - Dokki - Giza to be subjected to bacteriological examination.

\section{Examination of the collected samples:}

1- Total colony count (T.C.C.): Using poured plate technique method, 10-fold dilutions of each water and swab samples was used for determination of total bacterial load, on brain heart infusion agar (APHA, 2005). The plates were incubated for 1-2 days for fast growing bacteria at $37^{\circ} \mathrm{C}$ (APHA, 2005). The different isolated bacterial colonies were further identified according to Dufour-zavala et al. 2008.
2- Bacteriological examination of the collected samples: Samples collected for bacteriological examination were inoculated in peptone buffer, brain heart infusion broth (oxoid) and selenite-F broth (oxoid) then incubated at $37{ }^{\circ} \mathrm{C}$ for 24 hours. A loopfuls from each broth culture were inoculated onto sheep blood agar, brain heart infusion agar (oxoid), macConkey agar (oxoid) and XLD agar (oxoid) plates and incubated at $37 \mathrm{C}$ for 24 hours. Isolated colonies were picked up and identified morphologically, microscopically and biochemically according to Dufour-zavala et al. 2008.

Statistical Analysis: The Data obtained were statistically analyzed using t- test according to SPSS 14 (2006).

\section{RESULTS}

The results of the examination of the swab samples taken from different sites from both cage broiler and layer houses were recorded in tables $2 \& 3$. The results showed high initial contamination of cage houses specially in layer ones before cleaning and disinfection indicated by the high initial total colony counts of the collected swab samples. Also, there was highly significant reduction $(\mathrm{p}<0.001)$ in the total colony count (T.C.C.) from different sites after cleaning and disinfection with both disinfectants with a depletion percentage reached $99.999 \%$. The peroxygen products were more effective in reducing (T.C.C.) especially in the layer cage houses than the use of diluted formalin.

Table 2: The mean total colony counts of swab samples from Layer houses before cleaning and after cleaning and disinfection by different disinfectants.

\begin{tabular}{cccccc}
\hline \multicolumn{2}{c}{ samples } & $\begin{array}{c}\text { Disinfection } \\
\text { method }\end{array}$ & $\begin{array}{c}\text { Mean TCC (CFU/ml) } \\
\text { before disinfection }\end{array}$ & $\begin{array}{c}\text { Mean TCC(CFU/ml) } \\
\text { after disinfection }\end{array}$ & Depletion \% \\
\hline walls & 20 & 1 & $0.29 \times 10^{10}$ & $0.02 \times 10^{4^{*}}$ & 99,9999931 \\
\hline walls & 20 & 2 & $0.41 \times 10^{10}$ & $0.17 \times 10^{2^{*}}$ & 99,999999959 \\
\hline batteries & 20 & 1 & $3.7 \times 10^{10}$ & $1.3 \times 10^{4^{*}}$ & 99,999964886 \\
\hline batteries & 20 & 2 & $2.6 \times 10^{10}$ & $1.4 \times 10^{2^{*}}$ & 99,999999946 \\
\hline floors & 20 & 1 & $4.8 \times 10^{10}$ & $5.2 \times 10^{4^{*}}$ & 99,999989167 \\
\hline floors & 20 & 2 & $3.2 \times 10^{10}$ & $0.5 \times 10^{2^{*}}$ & 99,999999984 \\
\hline
\end{tabular}

\footnotetext{
${ }^{*}$ Significant at $\mathrm{P}<0.001$ using t-student test
} 
Table 3: The mean total colony counts of swab samples from broiler houses before cleaning and after cleaning and disinfection by different disinfectants.

\begin{tabular}{cccccc}
\hline \multicolumn{2}{c}{ Samples } & $\begin{array}{c}\text { Disinfection } \\
\text { method }\end{array}$ & $\begin{array}{c}\text { Mean TCC } \\
(\mathrm{CFU} / \mathrm{ml}) \\
\text { before disinfection }\end{array}$ & $\begin{array}{c}\text { Mean TCC } \\
(\mathrm{CFU} / \mathrm{ml}) \\
\text { after disinfection }\end{array}$ & Depletion \% \\
\hline walls & 20 & 1 & $0.14 \times 10^{10}$ & $0.12 \times 10^{2^{*}}$ & 99,99999914 \\
\hline walls & 20 & 2 & $0.17 \times 10^{10}$ & $0.08 \times 10^{2^{*}}$ & 99,99999953 \\
\hline batteries & 20 & 1 & $0.23 \times 10^{10}$ & $1.6 \times 10^{2^{*}}$ & 99,99999304 \\
\hline batteries & 20 & 2 & $0.31 \times 10^{10}$ & $1.1 \times 10^{2^{*}}$ & 99,99999645 \\
\hline floors & 20 & 1 & $3.2 \times 10^{10}$ & $0.4 \times 10^{2^{*}}$ & 99,99999988 \\
\hline floors & 20 & 2 & $7.8 \times 10^{10}$ & $0.2 \times 10^{2^{*}}$ & 99,99999997 \\
\hline
\end{tabular}

${ }^{*}$ Significant at $\mathrm{P}<0.001$ using t-student test

On the other hand, the bacteriological examination of the swab samples (table 4) revealed the isolation of different types of pathogenic contaminant bacteria including Bacillus spp., Staphylococcus aureus, E.coli, Coliforms, Pseudomonas earuginosa, and Salmonella typhymiurium from both broiler and layer houses before cleaning and disinfection. It was found that The Peroxygen products (Degaclean 51 and Peraclean 15) were able to overcome most of the isolated pathogenic contaminant bacteria from both cage layer and broiler houses while formalin failed to do that except for Salmonella typhymurium contamination as both disinfectants were able to decontaminate it in both broiler and layer houses

Table 4: Results of the bacteriological examination of broiler and Layer houses before and after cleaning and disinfection by different disinfectants.

\begin{tabular}{|c|c|c|c|c|}
\hline \multicolumn{2}{|c|}{ samples } & \multirow{2}{*}{$\begin{array}{l}\text { Isolated } \\
\text { microorganisms } \\
\text { before disinfection }\end{array}$} & \multirow{2}{*}{ 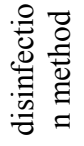 } & \multirow{2}{*}{$\begin{array}{l}\text { Isolated } \\
\text { microorganisms } \\
\text { after disinfection }\end{array}$} \\
\hline houses & site & & & \\
\hline \multirow{6}{*}{ Broiler } & \multirow[t]{2}{*}{ walls } & \multirow[t]{2}{*}{$\begin{array}{l}\text { Bacillus spp., Staphylococcus aureus, E.coli, } \\
\text { Coliforms \& Pseudomonas earuginosa }\end{array}$} & 1 & $\begin{array}{c}\text { Bacillus spp.,Staphylococcus aureus, } \\
\text { Coliforms, E.coli \& Pseudomonas } \\
\text { earuginosa }\end{array}$ \\
\hline & & & 2 & Bacillus spp. \\
\hline & \multirow[t]{2}{*}{ Batteries } & \multirow{2}{*}{$\begin{array}{c}\text { Bacillus spp.,Staphylococcus aureus, E.coli, } \\
\text { Coliforms, Pseudomonas earuginosa \& } \\
\text { Salmonella typhymiurium }\end{array}$} & 1 & $\begin{array}{c}\text { Bacillus spp.,Staphylococcus aureus, E.coli, } \\
\text { Coliforms\& Pseudomonas earuginosa, }\end{array}$ \\
\hline & & & 2 & Bacillus spp. \\
\hline & \multirow[t]{2}{*}{ floors } & \multirow{2}{*}{$\begin{array}{c}\text { Bacillus spp. ,Staphylococcus aureus, E.coli, } \\
\text { Coliforms, Pseudomonas earuginosa \& } \\
\text { Salmonella typhymiurium }\end{array}$} & 1 & $\begin{array}{c}\text { Bacillus spp.,Staphylococcus aureus, E.coli, } \\
\text { Coliforms \&Pseudomonas earuginosa, }\end{array}$ \\
\hline & & & 2 & Bacillus spp. \\
\hline \multirow{6}{*}{ Layer } & \multirow[t]{2}{*}{ walls } & \multirow{2}{*}{$\begin{array}{l}\text { Bacillus spp.,Staphylococcus aureus, E.coli, } \\
\text { Coliforms \& Pseudomonas earuginosa }\end{array}$} & 1 & $\begin{array}{c}\text { Bacillus spp.,Staphylococcus aureus, E.coli, } \\
\text { Coliforms\& Pseudomonas earuginosa, }\end{array}$ \\
\hline & & & 2 & Bacillus spp. \\
\hline & \multirow[t]{2}{*}{ Batteries } & \multirow{2}{*}{$\begin{array}{c}\text { Bacillus spp., Staphylococcus aureus, E.coli, } \\
\text { Coliforms, Pseudomonas earuginosa } \& \\
\text { Salmonella typhymiurium }\end{array}$} & 1 & $\begin{array}{l}\text { Bacillus spp.,Staphylococcus aureus, E.coli, } \\
\text { Coliforms\& Pseudomonas earuginosa }\end{array}$ \\
\hline & & & 2 & Bacillus spp. \\
\hline & \multirow[t]{2}{*}{ floors } & \multirow{2}{*}{$\begin{array}{c}\text { Bacillus spp., Staphylococcus aureus, E.coli, } \\
\text { Coliforms, Pseudomonas earuginosa } \& \\
\text { salmonella typhymiurium }\end{array}$} & 1 & $\begin{array}{l}\text { Bacillus spp.,Staphylococcus aureus, E.coli, } \\
\text { Coliforms\& Pseudomonas earuginosa, }\end{array}$ \\
\hline & & & 2 & Bacillus spp. \\
\hline
\end{tabular}


The examination of water samples from different sources of the farms revealed the sterility of the main source (well hard water) while the water from the main storage tank and the houses storage tanks showed sever contamination with different contaminant bacteria which incriminated in inducing outbreaks among poultry including Staphylococcus aureus, E.coli, coliforms, Pseudomonas earuginosa and Proteus spp. ( table 5). The water tanks were not enough protected against dropping of free living birds in addition to rodents and insects pollutions.

Table 5: Results of examination of water samples from different sources of water in both broiler and layer houses.

\begin{tabular}{ccccc}
\hline $\begin{array}{c}\text { place of water } \\
\text { sample }\end{array}$ & $\begin{array}{c}\text { No. of } \\
\text { samples }\end{array}$ & $\mathrm{pH}$ & $\begin{array}{c}\text { Mean TCC } \\
\text { (CFU/ML) }\end{array}$ & $\begin{array}{c}\text { ISOLATED } \\
\text { MICROORGANISMS }\end{array}$ \\
\hline Well water & 1 & 7.2 & 0 & - \\
\hline $\begin{array}{c}\text { Main storage } \\
\text { tank }\end{array}$ & 1 & 7.1 & $1.1 \times 10^{5}$ & $\begin{array}{c}\text { Bacillus spp., Staphylococcus aureus, } \\
\text { E.coli, Coliforms, Pseudomonas earuginosa. }\end{array}$ \\
\hline $\begin{array}{c}\text { Houses storage } \\
\text { tanks }\end{array}$ & 8 & 7.1 & $4.8 \times 10^{6}$ & $\begin{array}{c}\text { Bacillus spp., Staphylococcus aureus, E.coli, } \\
\text { Coliforms, Pseudomonas earuginosa \& Proteus spp. }\end{array}$ \\
\hline
\end{tabular}

On the other hand, on examination of the swab samples from the houses drinking water dispensers before and after cleaning and disinfection (tables $6 \&$ 7) revealed that although both of the disinfectant used had the ability to significantly $(\mathrm{p}<0.001)$ reduced the TCC of the isolated bacterial populations (table 6$)$ but the Peroxygen products (Degaclean 51 and Peraclean 15) were more effective in destroying the pathogenic contaminant bacteria (table 7).

Table 6: The mean total colony counts of swab samples from drinking water dispensers before and after cleaning and disinfection by different disinfectants.

\begin{tabular}{|c|c|c|c|c|c|}
\hline \multicolumn{2}{|c|}{$\begin{array}{l}\text { Drinking water dispensers } \\
\text { samples }\end{array}$} & \multirow{2}{*}{$\begin{array}{c}\text { disinfection } \\
\text { method }\end{array}$} & \multirow{2}{*}{$\begin{array}{c}\text { Mean TCC }(\mathrm{CFU} / \mathrm{ml}) \\
\text { before disinfection }\end{array}$} & \multirow{2}{*}{$\begin{array}{c}\text { Mean } \mathrm{TCC}(\mathrm{CFU} / \mathrm{ml}) \\
\text { after disinfection }\end{array}$} & \multirow{2}{*}{ Depleton \% } \\
\hline Sample no. & $\begin{array}{l}\text { No. of } \\
\text { swabs }\end{array}$ & & & & \\
\hline Sample 1 & 40 & 1 & $0.14 \times 10^{10}$ & 1. $2 \times 10^{6 *}$ & 99,91428571 \\
\hline Sample 2 & 40 & 2 & $0.23 \times 10^{10}$ & $0.6 \times 10^{2^{*}}$ & 99,99999739 \\
\hline $\begin{array}{l}\text { Significant at } \mathrm{P}<0.00 \\
\text { Table 7: Results o } \\
\text { cleaning an }\end{array}$ & $\begin{array}{l}1 \text { using t-stu } \\
\text { f the bacte } \\
d \text { disinfecti }\end{array}$ & $\begin{array}{l}\text { dent test } \\
\text { riological ex } \\
\text { on }\end{array}$ & xamination of drinking $\mathrm{v}$ & er dispensers before & aing and afte \\
\hline Drinkers samples & $\begin{array}{r}\text { Disin } \\
\text { me }\end{array}$ & $\begin{array}{l}\text { fection } \\
\text { thod }\end{array}$ & $\begin{array}{l}\text { Isolated microorganisms } \\
\text { before disinfection }\end{array}$ & $\begin{array}{l}\text { Isolated microor } \\
\text { after disinfec }\end{array}$ & $\begin{array}{l}\text { anisms } \\
\text { ion }\end{array}$ \\
\hline $\begin{array}{l}\bar{o} \\
\overline{\frac{a}{E}} \\
\text { ज̆ }\end{array}$ & & 1 & $\begin{array}{c}\text { Bacillus spp., } \\
\text { Staphylococcus aureus, }\end{array}$ & $\begin{array}{r}\text { Bacillus spp., Staphylo } \\
\text { E.coli, Coliforms, } P \\
\text { earuginos }\end{array}$ & $\begin{array}{l}\text { occus aureus, } \\
\text { eudomonas }\end{array}$ \\
\hline$\frac{\sim}{0}$ & & $P$ & $\begin{array}{c}\text { E.coli, Coliforms, } \\
\text { Pseudomonas earuginosa }\end{array}$ & Bacillus sp & \\
\hline
\end{tabular}




\section{DISCUSSION}

Cleaning and disinfection of poultry houses between production rounds is important to minimize infection and to eliminate pathogenic organisms. The current study was performed to evaluate 2 different categories of disinfectants commonly used in disinfection of poultry houses, formaldehyde and peroxygens under field circumstances. The programs in the study were based on those routinely used by the farmer to clean and disinfect the premises when the last flocks of broiler and laying hens were suffered from sanitary problem. The assessment of decontamination efficiency involves determining the number of viable microorganisms present on surfaces (Drouin and Toux, 1985).

In this investigation bacteriological monitoring highlighted the contamination of in battery cage houses with serious contaminant bacteria before cleaning and disinfection indicated by high total colony count of the collected swab samples of both broiler and layer houses. These high initial contamination results referred to the severe contamination of cage systems with the dropping belts, manure conveyors on the floor in addition to the cleaning difficulties especially in layer houses.

The obtained data after cleaning and disinfection indicating a lower standard of cleaning process was achieved in battery cage houses especially in layer cage houses before the disinfection application which reflected on the decontamination effect of disinfectants used especially formaldehyde to induce their action as cleaning is made difficult by the complexity of cage equipment and the inaccessibility of certain parts. These results agreed with Wales et al. (2006) who reported that Laying houses are notoriously difficult to clean thoroughly because of their intrinsically complicated structures, which are even more complex in the case of cage laying houses.

Also, the data collected showed that dilution errors might be occurred in formaldehyde treatment, which was performed by farm's workers. These results agreed with that obtained by many authors (Moustafa et al., 2009; Huneau-Salau et al., 2010) which underlines the necessity of improving farmers' and hygiene specialists' education on the use of disinfecting products in animal husbandry.

On the other hand, disinfectants may have a limited lifespan after their initial dilution and it is possible that heat, sunlight, humidity, time of application, organic matter, and adulterants may reduce their efficacy as the correct usage of disinfectants is an important component of a successful biosecurity program (Santos and Falconi, 2007 and Stringfellow et al., 2009).
Both disinfectants were able to overcome Salmonella typhymiurium contamination which detected in both broiler and layer houses which agreed with the results obtained by many authors (Carrique-Mas et al., 2009; Stringfellow et al., 2009; Dewaele et al., 2011 and McLarene et al., 2011).

Clean and fresh water free from pathogens is extremely important in poultry production and in the biosafety program of poultry farms to get best performance. There is another issue that can affect clean water supply which is the formation of "biofilm" in water pipes. A bio film is an aggregate of microorganisms surrounded and adhered to a surface by a slim substance in the water distribution system that may be difficult to clean between the batches. Bio film provides a haven to water borne pathogens.

In this investigation the water sample from the well source was sterile while that taken from water storage system and drinking water dispensers were heavily contaminated with different contaminated water born bacteria which constituted health hazard of poultry sanitation including Staphylococcus aureus, E.coli, coliforms, Pseudomonas earuginosa and Proteus spp. (tables 5\&7). These results agreed with Cretikos et al. (2010) and Ferguson et al. (2011) who reported that there are supply system factors affecting the microbiological drinking water safety and drinking water systems without disinfection and appear to affects of water pollution, which presents a risk of waterborne disease outbreaks.

It was noticed that the water tanks were not enough protected against dropping of free living birds in addition to rodents and insects pollutions which constituted a serious threaten in the success of disinfection process and biosecurity program.

After cleaning and disinfection there was a huge decline in the bacterial load in drinkind water dispensers which indicated by lowered mean total bacterial count in both types of disinfectant used but peroxygen products were more efficient in destroying the pathogenic contaminant bacteria (tables 6,7). The peroxygen product used consisted of two components : (Degaclean 51) which used in removing of organic matter and biofilm before disinfection of poultry houses which greatly increased the disinfection efficiency of the second product (Peraclean 15) in destroying the contaminant bacteria. Furthermore, the application of the peroxgen products were performed under supervision of hygiene specialists that were more careful in applying the disinfectants according to the manufacturers' recommended working concentrations. multiple factors should be considered when a disinfectant is chosen, such as organic matter on the surface to be treated, presence of organic matter in the dilutent, quality of water, corrosiveness or toxicity of the product, application method, 
temperature, porosity of the surface being treated, length of contact time, infectious organisms targeted, susceptibility of the infectious organisms, and correct dilution (Prince et al., 1991; Quinn and Markey, 2001; Dvorak, 2005; Payne et al., 2005 and Stringfellow et al., 2009).

On conclusion, a high standard planning of cleaning is of great importance perior to the application of the disinfection process and the correct usage of disinfectants in addition to effective program of eradication of rodent and insects are important components of a successful biosecurity program (Santos and Falconi, 2007; Stringfellow et al., 2009). Also, which underlines the necessity of improving farmers' and hygiene specialists' education on the use of disinfecting products in poultry houses. It was recommended to use more environmental friendly safe and also efficient peroxegen disinfectants to alternate to the use of formaldehyde products which should be declined due to the strong, irritant odour, corrosiveness, fibrolytic properties and toxicity (Samberg and Meroz 1995). Also, the use of formaldehyde may soon become illegal in some countries due to environmental concerns.

\section{REFERANCES}

Anonymous (2008): Guide of good hygiene practice for the prevention and control of microbiological infections focused on Salmonella control of chickens reared for meat. AVEC (Association of Poultry Processors and Poultry Trade in the EU) and COPA-COGECA (Committee of Professional Agricultural Organisations in the European Union/General Confederation of Agricultural Co-operatives in the European Union). Available online at www.food.gov.uk/ multimedia/pdfs/ comguidsalmonella.pdf (accessed 14 June 2010).

Anonymous (2010): Community guide for good hygiene practices in pullet rearing and egg laying flocks. EUWEP (European Union of Wholesale with Eggs Egg Products Poultry and Game) and COPACOGECA (Committee of Professional Agricultural Organisations in the European Union/General Confederation of Agricultural Cooperatives in the European Union). Available online at http://ec. europa.eu/food/food/biosafety/salmonella/docs /community_guide_layers__ygiene_practice_ pullet_egg_en.pdf

APHA [American Public Health Association], (2005): Standard Methods for the Examination of Water and Wastewater $21^{\text {st }}$ ed. APHA, Inc. Washington, D C.

Bessems, E. (1998): The effect of practical conditions on the efficacy of disinfectants. International
Biodeterioration and Biodegradation, 41: 177-183.

Brown, M.R.W.; Costerton, J.W. and Gilbert, P. (1991): Extrapolating to bacterial life outside the test tube. Journal of Antimicrobial Chemotherapy, 27: 565-567.

Carrique-Mas, J.J.; Marin, C.; Breslin, M.; McLaren, I. and Davies, R. (2009): A comparison of the efficacy of cleaning and disinfection methods in eliminating Salmonella spp. from commercial egg laying houses. Avian Pathology, 38: 419-424.

Chapman, J.S. (2003): Biocide resistance mechanisms. International Biodeterioration and Biodegradation, 51: 133-138.

Cobb-Vantress (2003): COBB 500 guia de manejo de matrizes. Guapiaçu, SP: COBB In: Relationship between ecological concepts and biosafety in broiler breeder farms.

Cretikos, M.; Byleveld, P.; Durrheim, D.N.; Porigneaux, P.; Merritt, T. and Leask, S. (2010): Supply system factors associated with microbiological drinking water safety in regional New South Wales, Australia, 20012007. J, Water Health. 2010 Jun; 8(2): 257-68.

Davison, S.; Benson, C.E. and Eckroade, R.J. (1996): Evaluation of disinfectants against Salmonella enteritidis. Avian Diseases, 40: 272-277.

Dewaele, I.; Ducatelle, R.; Herman, L.; Heyndrickx, M. and De Reu, K. (2011): Sensitivity to disinfection of bacterial indicator organisms for monitoring the Salmonella Enteritidis status of layer farms after cleaning. Poultry Science 90:1185-1190

Doerning, B.J. (1998): Sanitation concerns. In Proc. $135^{\text {th }}$ Annual meeting of the American veterinary medical association (AVMA), 25-29 July, Baltimore, Maryland. AVMA, Schaumburg, Illinois, 162-164.

Drouin, P. and Toux, J.Y. (1985): Me'thode bacte'riologique pour appre'cier la de'sinfection des poulaillers. Bulletin d'Information de la Station Expe'rimentale d'Aviculture de Ploufragan, 25: 176-178.

Dufour-zavala, L.; Swayne, D.E.; Glisson, J.R.; Pearson, J.E.; Reed, W.M.; Jackwood, M.W. and Woolcock, P.R. (2008): A laboratory manual for the isolation, identification and characterization of avian pathogens. $5^{\text {th }} \mathrm{ed}$, american association of avian pathologists, 12627 San Jose Blvd., Suite 202 Jacksonville, FL 32223-8638.

Dvorak, G. (2005): $\quad$ Disinfection 101. http://www.cfsph.iastate.edu.

Eckman, M.K. (1994): Chemicals used by the poultry industry. Poultry Sci. 73:1429-1432.

Ferguson, A.S.; Mailloux, B.J.; Ahmed, K.M.; Van Geen, A.; McKay, L.D. and Culligan, P.J. (2011): Hand-pumps as reservoirs for 
microbial contamination of well water. J. Water Health. (Dec) 9 (4): 708-17.

Gorman, S.P.; Scott, E.M. and Russell, A.D. (1980): Anti-microbial activity, uses and mechanism of action of glutaraldehyde. Journal of Applied Bacteriology, 48: 161-190.

Huneau-Salau, N.A.; Michel, V.; Balaine, L.; Petetin, I.; Eono, F.; Ecobichon, F. and Le Bouquin, $S$. (2010): Evaluation of common cleaning and disinfection programmes in battery Cage and on-floor layer houses in France. British Poultry Science Volume 51, Number 2 (April), pp. 204-212

Lauandos, I.P.; Kondo, N. and Lima, E.A. (2005): A Biosseguridade exigida em granjas de avs e matrizes. Avicultura Industrial, (8):22-31.

McDonnell, G. and Russell, A.D. (1999): Antiseptics and disinfectants: activity, action, and resistance. Clinical Microbiology Reviews, 12: 147-179.

McLaren, I.; Wales, A.; Breslin, M. and Davies, R. (2011): Evaluation of commonly-used farm disinfectants in wet and dry models of Salmonella farm contamination. Avian Pathology (February) 40(1): 33-42.

Moustafa, G.Z.; Anwer, W.; Amer, H.M.; EL-Sabagh, I.M.; Rezk, A. and Badawy, E.M. (2009): In vitro efficacy comparisons of disinfectants used in the commercial poultry farm. International Journal of Poultry Science 8 (3): 237-241, 2009.

Payne, J.B.; Kroger, E.C. and Watkins, S.E. (2005): Evaluation of disinfectant efficacy when applied to the floor of poultry growout facilities. J. Appl. Poult. Res. 14:322-329.

Prince, H.L.; Prince, D.L. and Prince, R.N. (1991): Principles of viral control and transmission. Pages 411-444 in Disinfection, Sterilization and Preservation. 4th ed. S. S. Block, ed. Lea and Febiger, Philadelphia, PA.

Quinn, P.J.; and Markey, B.K. (2001): Disinfection and disease prevention in veterinary medicine. Pages 1069-1103 in: Disinfection, Sterilization and Preservation, 5th ed. S. S. Block, ed. Lippincott, Williams and Wilkins, Philadelphia, PA.

Rodgers J.D.; McCcullagh, J.J.; McNamee, P.T.; Smith, J.A. and Ball, H.J. (2001): An investigation into the efficacy of hatchery disinfectants against strains of staphylococcus aureus associated with poultry industry. Vet. Microbiol., 82, 131-140.

Russell, A.D. (2004): Factors influencing the efficacy of antimicrobial agents. In A.P. Fraise, P.A. Lambert and J.-Y. Maillard (Eds.). Russell, Hugo and Ayliffe's Principles and Practice of Disinfection, Preservation and Sterilization (pp. 98 127). Oxford, UK: Blackwell.

Samberg, Y. and Meroz, M. (1995): Application of disinfectants in poultry hatcheries. Rev. sci. tech. Off. int. Epiz., 14 (2), 365-380

Santos, C.A. and Falconi, F.A. (2007): Brazilian Journal of Poultry Science, Jul - Sep, volume 9, no.3: $151-155$.

Santos, C.A. and Falconi, F.A. (2007): Relationship between ecological concepts and biosafety in broiler breeder farms. Brazilian Journal of Poultry Science, Jul - Sep, volume 9, no.3: 151-155.

SPSS 14 (2006): "Statistical Package for Social Science, SPSS for windows Release 14.0.0, 12 June, 2006." Standard Version, Copyright SPSS Inc., 1989-2006, All Rights Reserved, Copyright $₫$ SPSS Inc.

Stringfellow, K.; Anderson, P.; Caldwell, D.; Lee, J.; Byrd, J.; McReynolds, J.; Carey, J.; Nisbet, D. and Farnell, M. (2009): Evaluation of disinfectants commonly used by the commercial poultry industry under simulated field conditions. Poultry Science, 88: 1151-1155.

Wales, A.; Breslin, M. and Davies, R. (2006): Assessment of cleaning and disinfection in Salmonella-contaminated poultry layer houses using qualitative and semi-quantitative culture techniques. Veterinary Microbiology, 116: 283-293.

Ward, P.; LaForge, M.; Gibson, S.; McMullen, L. and Fasenko, G. (2005): Broiler barn surface type and presence of organic material influences the ability of disinfectants to reduce bacterial populations. Poultry Science, 84 (Suppl. 1): 61-62.

Wierup, M. (2000): The control of microbial diseases in animals: Alternative to the use of antibiotics. Int. J. Antimicrobial agents, 14: 315-319. 


\section{تقييم برامج للتطهير باستخدام مطهرات مختلفة في تطهير مساكن الدواجن تحت الظروف الحقلية}

\section{جيهان مصطفى بلر ، آمال إبراهيم يوسف}

Email: Jihanbdr@yahoo.com

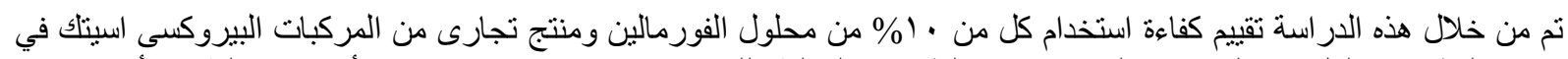

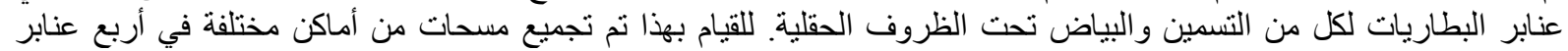

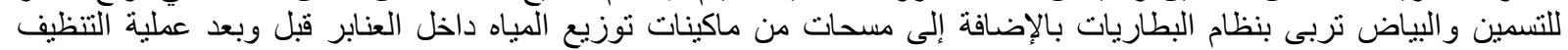

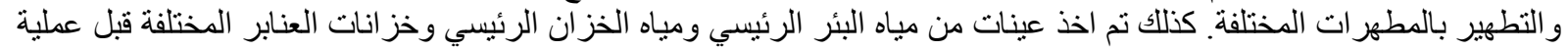

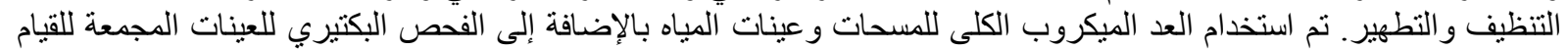

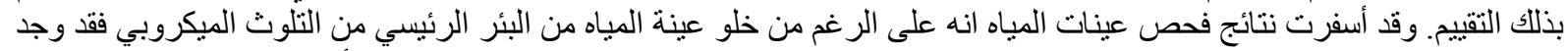

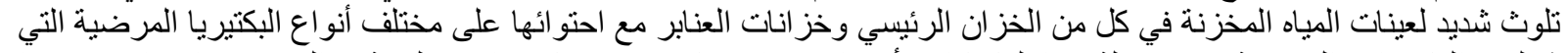

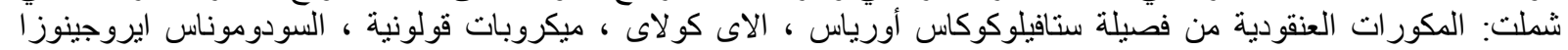

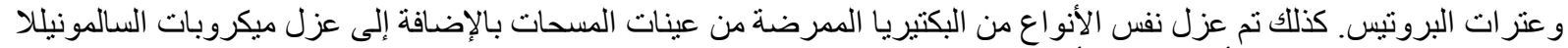

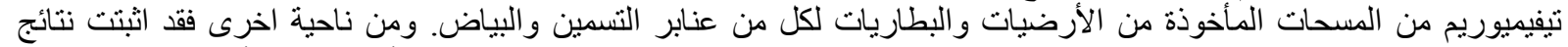

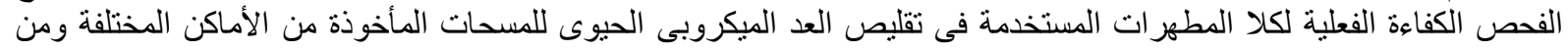

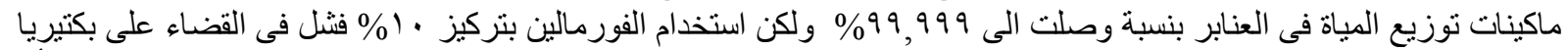

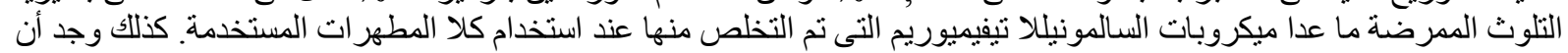

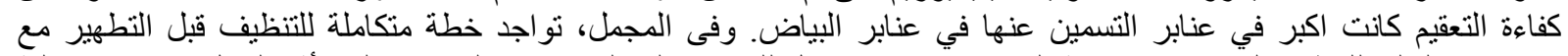

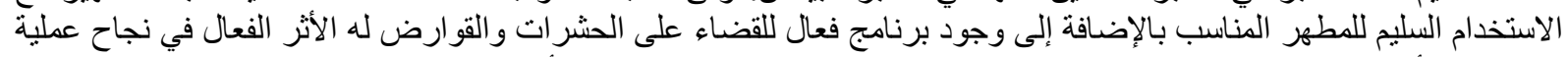

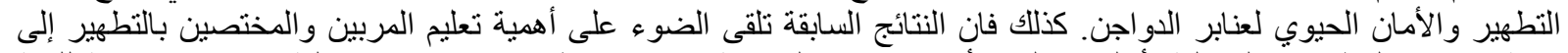

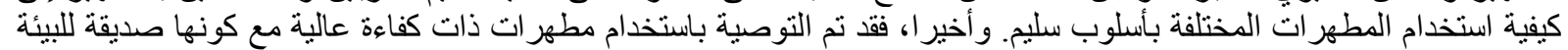

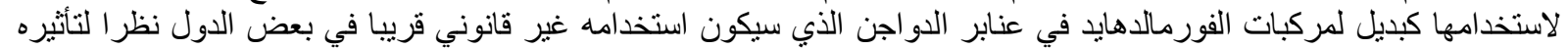
الصحي الضار وخطره البيئي. 